\title{
PROFIT SHIFTING AND THE TAX RESPONSE OF MULTINATIONAL BANKS IN EASTERN EUROPE
}

\author{
Daniel Anarfi ${ }^{1}$, Danuše Nerudová ${ }^{1}$ \\ ${ }^{1}$ Department of Accounting and Taxation, Faculty of Economics, Mendel University in Brno, Zemědělská 1, \\ 61300 Brno, Czech Republic
}

\begin{abstract}
ANARFI DANIEL, NERUDOVÁ DANUŠE. 2018. Profit Shifting and the Tax Response of Multinational Banks in Eastern Europe. Acta Universitatis Agriculturae et Silviculturae Mendelianae Brunensis, 66(3): 729-736.

The aim of the paper is to measure the amount of profit shifting within the banking sector in Eastern European countries. The paper uses firm-level bank data from the Bankscope database of multinational subsidiary banks operating in Eastern Europe for a period of 10 years (2006-2015). An empirical analysis is performed on the panel data to identify the profit-shifting activities of these banks. Focusing on the banking sector of Eastern European countries, which are a microcosm of the European Union, substantial evidence of profit shifting is found and confirms that banks have enhanced tax-planning opportunities similar to firms from different jurisdictions. The paper also seeks to contribute to recommendations on how fair and sustainable taxation and social policy reforms can increase the economic stability of the EU member states.
\end{abstract}

Keywords: profit shifting, multinationals, subsidiary banks, Eastern Europe

\section{INTRODUCTION}

The debate on base erosion and profit-shifting activities undertaken by multinational corporations (MNCs) is continuing unabated in the public domain, as heads of states, developmental organizations, and the international media have in recent times raised many concerns about the growing activities of aggressive tax planning. The debate has recently been stirred up by the unprecedented leak of approximately 11.5 million documents, the "Panama Papers", from the database of the offshore law firm Mossack Fonseca, spanning the period from the 1970s to spring 2016. The Panama Papers basically expose how some of the world's leaders and most influential people have allegedly used offshore accounts and "shell companies" to avoid paying taxes. Multinational companies, such as Apple, Google, and Starbucks, have also come under heavy criticism recently with regard to their considerable involvement in profit shifting and aggressive tax planning, especially in relation to their British sales, based on anecdotal evidence.
The financial crisis in 2008 and the colossal amount of public money invested to stabilize the financial sector caused huge pressure on the national budgets, therefore attracting increasing attention to the collection of taxes and fiscal strains in many countries, especially among MNCs and the financial sector. This point to the fact that companies set up complicated tax structures to indulge in aggressive tax-planning practices to shift income from high-tax to low-tax locations. When MNCs engage in tax planning, the possible motive is to shift profits to erode the taxable base to locations where they are subject to more favourable tax treatment (OECD, 2013).

In response to the need for a solution to this problem, several initiatives, collaborations, and developments have been undertaken by world leaders and various organizations. In May 2012 for instance, the G-20 leaders held a meeting in Mexico to reiterate the need to prevent base erosion and profit-shifting (BEPS) activities by MNCs. At the meeting the world leaders affirmed their decision to follow closely the concrete 15-action plan to tackle BEPS by the Organisation for Economic Cooperation and Development (OECD), 
which was later produced in July 2013 and the final reports presented in October 2015. Dharmapala (2014) alluded to the fact that the 15-item action plan that was released by the OECD is intended to facilitate multilateral cooperation among governments with regard to the taxation of MNCs. Furthermore, a joint task force initiative has been introduced by the International Monetary Fund (IMF), the Organisation for Economic Co-operation and Development (OECD), the UN Department of Economic and Social Affairs (DESA), and the World Bank Group. This Platform for Collaboration on Tax has purposely been tasked to produce measures to support developing countries in combatting BEPS with respect to sharing information, building capacity, and delivering guidance, among others. Very recently, in October 2016, the European Commission also announced new reforms in corporate tax- and BEPS-related activities. The reforms consist of three separate measures: (1) a two-stage proposal towards a common consolidated corporate tax base (CCCTB); (2) a directive on double taxation dispute resolution mechanisms in the EU; and (3) amendments to the Anti-Tax Avoidance Directive (ATAD) relating to hybrid mismatches with third countries.

The extant literature on international tax planning has largely provided ample evidence of BEPS and aggressive tax planning in different jurisdictions (Buettner and Wamser, 2013; Crivelli et al., 2016; Finke, 2013; Huizinga and Laeven, 2008; Weichenrieder, 2009). Research on the profit-shifting activities of MNCs has mostly been associated with the non-financial industry (Clausing, 2016; Haufler and Schjelderup, 2000; Hines and Rice, 1994; Huizinga and Laeven, 2008; Krautheim and Schmidt-Eisenlohr, 2011). A few studies have also been conducted in the area of tax effects on capital structures. For instance, Desai, Foley, and Hines (2004) analysed the capital structures of foreign affiliates and the internal capital markets of multinational corporations. They found that $10 \%$ higher local tax rates are associated with $2.8 \%$ higher debt/asset ratios, with internal borrowing being particularly sensitive to taxes. Huizinga, Laeven, and Nicodeme (2008) also found that a foreign subsidiary's capital structure reflects the local corporate tax rates as well as the tax rate differences vis-à-vis the parent firm and other foreign subsidiaries. They therefore suggested that ignoring the international debt shifting arising from differences in national tax rates would understate the impact of national taxes on debt policies by about $25 \%$. However, the financial sector has fallen short and has seen few studies on this evidence. Demirgüc-Kunt and Huizinga (2001) examined the taxation of domestic and foreign-owned banks as well as conducting an investigation into whether domestic and foreign banks pay different amounts of domestic tax. Their study revealed that the taxes paid by foreign banks are shown to raise relatively little with the local statutory tax. Merz and Overesch (2016) also examined multinational banks' response to taxation. Using firm-level bank data, the authors found significant tax effects of profit shifting on the reported profits of bank subsidiaries, but the consequences reduced after the financial crisis in 2008.

The need to examine the profit-shifting activities of MNCs in the banking sector is further strengthened by the evidence found by Merz and Overesch (2016) suggesting that banks have enhanced tax-planning opportunities, similar to firms from the IT industry or the retailing sector. The aim of the paper is therefore to measure the amount of profit shifting within the banking sector in Eastern European countries. Specifically, the study examines the effect of multinational banks taking advantage of the differential rate in corporate tax of the host countries, particularly due to different business models. For the purpose of this study, we use a micro-level panel database of 45 subsidiary multinational banks from 14 countries in Eastern Europe as defined in Amadeus over a period of 10 years. The countries under consideration are Belarus, Bulgaria, Croatia, the Czech Republic, Estonia, Hungary, Latvia, Macedonia, Moldova, Poland, Romania, Serbia, Slovakia, and Ukraine.

\section{Literature Review}

The theoretical underpinnings of the estimation of BEPS can be explained by the "Hines-Rice" (HR) approach, which stem from Hines and Rice (1994). According to Dharmapala (2014), the HR approach operates on the premise that the observed pre-tax income of a subsidiary firm constitutes the sum of "true" income and "shifted" income. True income is derived by the subsidiary firm using capital and labour inputs. Shifted income, on the other hand, is the measure of the tax rate differential between two subsidiaries, which is the incentive to move profit in or out of a subsidiary. The HR approach largely focuses on the semi-elasticity of the tax differences, which represents the percentage change in pre-tax income associated with a 1 percentage point change in the tax rate (Dharmapala, 2014). Since its introduction the HR approach has been widely used by several authors and the magnitude of BEPS found has been enormous and varied.

To start with Huizinga and Laeven (2008) used a unique data set that contains detailed firm-level information on the parent companies and subsidiaries of European multinationals and detailed information about the international tax system to test and examine empirically the extent of intra-European profit shifting by European multinationals. The authors considered profit shifting arising not only from the international tax differences between affiliates and parent companies but also from the tax differences between affiliates in different host countries. Their finding was semi-elasticity of reported profits with respect to the top statutory tax rate of 1.43 , while shifting costs were estimated to be $1.6 \%$ of the tax base. 
In 2009 a 10 percentage point increase in the parent's home country tax rate, leading to roughly half a percentage point increase in profitability, was the BEPS evidence found by Weichenrieder (2009). The author considered profit-shifting behaviour in the EU using data on German inbound and outbound FDI. The study also found an empirical correlation between the home country tax rate of a parent and the net tax profitability of its German affiliate, which is consistent with profit-shifting behaviour.

Heckemeyer and Overesch (2013) also predicted tax semi-elasticity of subsidiary pre-tax profits of about 0.8 using the meta-regression approach to identify estimates from 25 studies and the existing literature. The authors estimated the tax response through financial planning from the transfer pricing and licensing channel, and their results suggest that transfer pricing and licensing are the dominant profit-shifting channel.

The use of panel data and affiliate fixed effects in estimating BEPS has also been considered extensively. Dischinger (2010) used a large micro database of European MNEs that includes detailed accounting and ownership information (AMADEUS) to provide indirect empirical evidence of profit-shifting behaviour by multinational enterprises (MNEs), employing a panel study for the years 1995 to 2005 while controlling for unobservable fixed firm effects. The study also found that a 10 percentage point decrease in the tax rate of the affiliate increases its pre-tax profitability by $7 \%$.

Lohse and Riedel (2013) also used panel data from Amadeus to investigate empirically whether national tax laws implemented by transfer-pricing legislation, which is intended to limit the leeway of multinational firms to exploit international corporate tax rate differences and relocate profit to low-tax affiliates, are instrumental in restricting shifting behaviour. The study found semi-elasticity of about 0.4 and further suggested that transfer-pricing rules significantly reduce shifting activities.

The role of internal debt as a vehicle for shifting profits to low-tax countries was also explored by Buettner and Wamser (2013). Using data on German multinationals, their study exploited the differential tax rate in more than 100 countries over 10 years. The results established that internal debt is used more by multinationals with affiliates in low-tax countries and increases with the spread between the host-country tax rate and the lowest tax rate among all the affiliates. However, because the tax effects found in the study were small, the authors suggested that profit shifting by means of internal debt is rather unimportant for German firms.

In the banking sector, firm-level bank data from the Bankscope database were used by Merz and Overesch (2016) to analyse how multinational banks respond to taxation. The authors found significant tax effects on the reported profits of bank subsidiaries and that the magnitude of the tax response of the reported profits was double the effects found in previous studies for non-financial MNCs. Our aim, particularly for this paper, is to focus our attention on Eastern Europe, which is a microcosm of the European Union, and to estimate the magnitude of BEPS undertaken by multinational bank subsidiaries.

Langenmayr and Reiter in 2017 used a novel and bank-specific method of profit shifting thus the strategic relocation of proprietary trading to low-tax jurisdictions to show how banks shift profits to low-tax countries. They used a regulatory data from the German central bank and the results showed that a one percentage point lower corporate tax rate increases banks' proprietary fixed-income trading assets by $2.2 \%$ and trading derivatives by $6.3 \%$.

\section{MATERIALS AND METHODS}

This study measure the amount of profit shifting within the banking sector in Eastern European countries.

\section{Data Description}

For the purpose of this study, we collected comprehensive bank data from the Bankscope Database compiled by Bureau Van Dijk for 14 countries in Eastern Europe. We use a data set of 45 foreign subsidiary banks over a period of 10 years from 2006 to 2015, yielding a total of 450 year-bank observations. A subsidiary bank is defined in this study as a bank in which at least $50 \%$ of the shares are owned and controlled by the parent company. Banks that have negative earnings before tax are excluded from the database, because we want to consider profit-making companies that have the motivation to shift or receive profits from different subsidiaries. We only consider private commercial banks; therefore, we exclude central banks, specialized governmental credit institutions and micro-finance institutions, and banks with insufficient tax information from our data compilation. Although this paper aims to achieve it's objective, the limitation of the study is that the research was uniquely conducted on a small sample of population compared to previous studies.

\section{Model Construction}

A few studies have used transfer pricing and estimations of deviation from arm's-length prices to find evidence of profit shifting (Bernard, Jensen, and Schott, 2006; Clausing, 2003; Swenson, 2001). Other previous studies have also dealt extensively with tax planning and profit shifting in industries other than the financial industry (Bagwell and Staiger, 2012; Dischinger, Knoll, and Riedel, 2014; Maffini and Mokkas, 2011; Peralta, Wauthy, and Van Ypersele, 2006). This study, however, investigates whether multinational banks take advantage of the corporate tax differentials among subsidiaries by focusing on the financial sector in Eastern Europe, which 
is a microcosm of the European Union, unlike previous studies in which large data sets have been used across the globe. The Hines-Rice approach (the HR approach) has been referred to as the most frequently used model in the estimation of profit shifting. According to Dharmapala (2014), the basis for this approach is that the unobserved profit before tax (PBT) of subsidiary $i$ at time represents the sum of "true" profit and "shifted" profit (where the latter can be either positive or negative). The firm theory assumes that capital and labour inputs are used to generate true profit. Following the work of Merz and Overesch (2016) and other previous studies, we use the common estimation shown below in this study.

$$
\begin{aligned}
& \mathrm{PBT}_{i t}=\alpha_{0}+\alpha_{1} \tau_{i t}+K A P_{i t}+L A B_{i t}+\alpha_{2} X_{i t}+ \\
& +\rho_{t}+\phi_{i t}+\varepsilon_{i t}
\end{aligned}
$$

As indicated earlier, the capital (KAP) and labour $(L A B)$ inputs are included to predict the counterfactual "true" profit. Dischinger (2010) provided a contrary view that the inclusion of labour and capital does not significantly affect the coefficient estimate of the tax differential. $X_{\text {it }}$ is a vector of additional subsidiary-level control characteristics. The coefficient of interest, $\alpha_{1}$, is used to identify the shifted profit and the tax incentive to move profit in or out of the subsidiary. Therefore, we expect $\alpha_{1}<0$ to obtain an indirect evidence of profit shifting, which is tax semi-elasticity of the reported profits. Variables $\rho_{t}$ and $\phi$ represent the control for heterogeneity across banks by a bank-specific effect and random term, respectively. $\varepsilon_{i}$ is the error term, and $\alpha_{1}$ is the constant.

\section{Variable Description}

This study follows the previous literature in using earnings before taxes (PBT, in logs) of the bank subsidiary as its dependent variable. The work of Merz and Overesch (2016) is followed by applying other variables, such as net interest revenue, non-interest operating income, and revenue from net fees and commissions as additional dependent variables to conduct a test on the differences in the tax response across different business models. Again the loan loss provisions (LLPs) and the total debt-to-total assets ratios (LEVERAGE) are used.

To control for bank characteristics, the variable $K A P_{i t}$ defines subsidiary $i$ 's capital inputs (a proxy by total assets), and $L A B_{i t}$ defines subsidiary $i$ 's labour inputs (proxied for instance by employment compensation). The off-balance sheet (OBS) items are the variable used to capture the subsidiary banks' activities that do not appear on the balance sheet. Additional bank-level variables include earning assets to total assets (EATA), which captures banks' assets used to generate interest income, and GROWTH (the annual change in the total assets of banks). We also follow the work of Gropp and Heider (2010) and Merz and Overesch
(2016) and use total securities, T-Bills, and other bills as banks' COLLATERAL; PROF is used as a profitability measure defined as net income with interest expenses/total assets; and PIOP, which is the pre-impairment operating profits, is used to control for profitability before loan loss provisioning (Merz and Overesch, 2016).

The tax variable used is the statutory corporate tax rate (CTR) of the bank subsidiary's host country. This is the incentive to shift taxable profits to and from the subsidiary banks. Merz and Overesch (2016) asserted that there is a need to include the average tax rate (ATAX) within the multinational banking group of which the subsidiary bank in question is excluded. This is to account for the incentives existing within the multinational bank, and a positive coefficient is expected. MTAX is the minimum tax rate that exists within the multinational group and is used to indicate a lower incentive to shift profits. We assume that the entire countries under consideration use uniform transfer-pricing rules and a common rule of law.

\section{RESULTS AND DISCUSSION}

This section presents the regression results of the impact of tax on the reported profits of our multinational subsidiaries in the banking sector.

\section{Effect of Tax on Reported Profits}

The table below is used to start our analysis of the impact of tax on reported profits using (ln) PBT as the dependent variable. We first perform a random-effect panel analysis for the period 2006-2015. Our basis for finding evidence of profit shifting, as used in the literature, is that we expect the coefficient $\alpha_{1}<0$.

From our regression results, a negative coefficient is found but no significant effect of the host country tax rate on the reported profits. Although the evidence found is not significant, it seems to suggest that bank subsidiaries with higher tax in host countries have smaller pre-tax profit and confirms our argument regarding how multinational banks respond to taxes with their reported profits in host countries. The coefficient of the variable CTR, yielding the result of 1.106, suggests that every 1 percentage point increase in the host country tax rate is associated with about 1.1\% lower reported profits of a bank subsidiary.

This estimated result, which shows evidence of profit shifting, confirms the findings of previous studies. For instance, Merz and Overesch (2016) also found evidence of semi-elasticity of -2.378 in the banking industry. Our results also confirm the results of Dischinger (2010) and Huizinga and Laeven (2008), which provided evidence of profit shifting in other jurisdictions. The ATAX and MTAX are included in columns (3) and (4), for which a positive coefficient is expected but the opposite is obtained. 
I: Summary Statistics

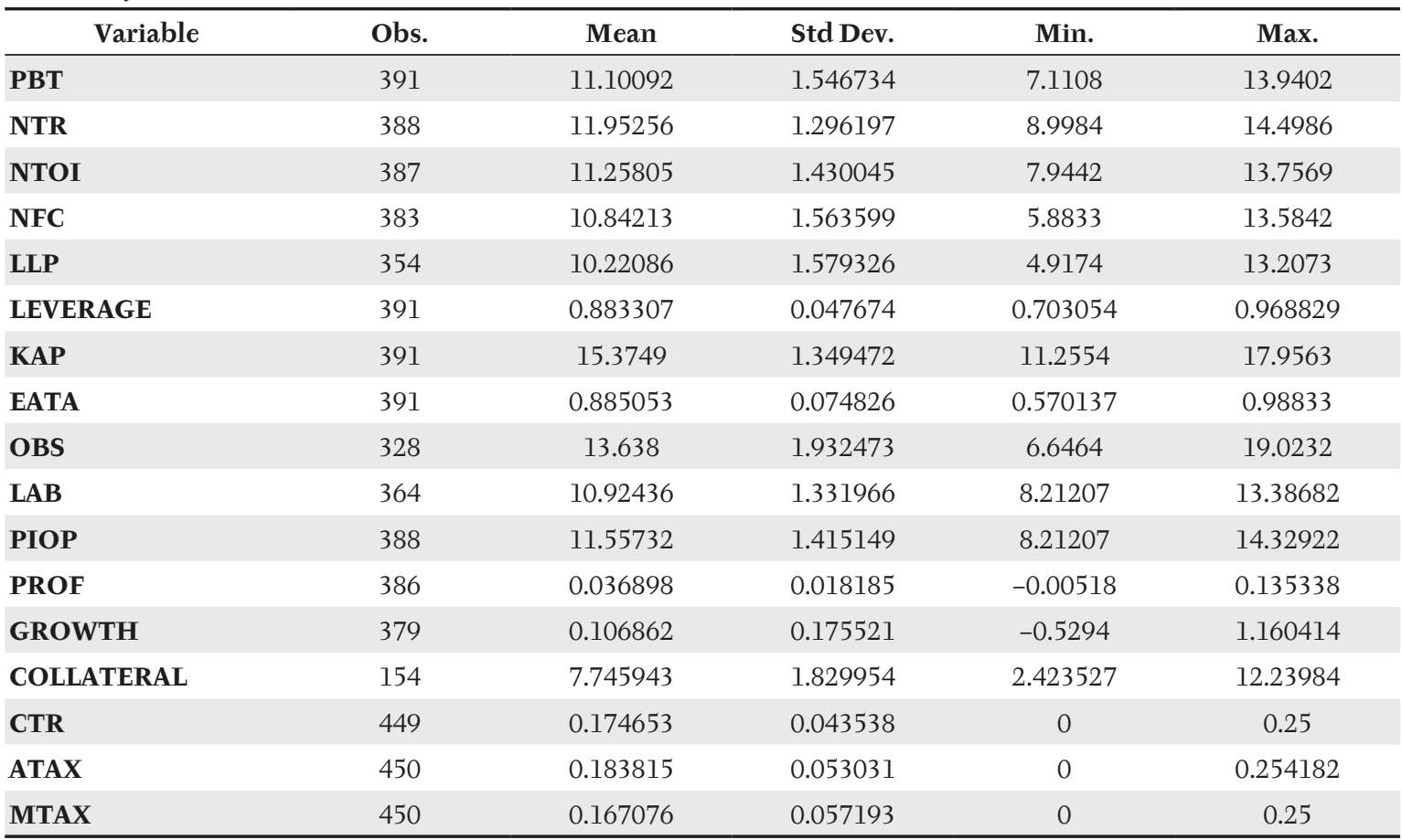

Source: Authors' estimations

II: Banks' Profit Shifting

\begin{tabular}{|c|c|c|c|c|}
\hline & $(1)$ & $(2)$ & (3) & $(4)$ \\
\hline & PBT & PBT & PBT & PBT \\
\hline \multirow{2}{*}{ CTR } & -1.106 & -0.693 & 0.253 & 0.0582 \\
\hline & $(-0.54)$ & $(-0.39)$ & -0.08 & -0.02 \\
\hline \multirow{2}{*}{ KAP } & 0.228 & $0.929 * * *$ & $0.907^{* *}$ & $0.914 * *$ \\
\hline & -0.81 & -3.35 & -3.17 & -3.18 \\
\hline \multirow{2}{*}{ EATA } & 0.314 & 1.756 & 1.835 & 1.894 \\
\hline & -0.28 & -1.78 & -1.83 & -1.86 \\
\hline \multirow{2}{*}{ OBS } & 0.0975 & -0.0196 & -0.0208 & -0.0142 \\
\hline & -1.25 & $(-0.28)$ & $(-0.30)$ & $(-0.20)$ \\
\hline \multirow{2}{*}{ LAB } & $0.766^{* *}$ & 0.239 & 0.268 & 0.25 \\
\hline & -2.78 & -0.95 & -1.02 & -0.93 \\
\hline \multirow{2}{*}{ GROWTH } & 0.904 & $1.460 * *$ & $1.462^{* *}$ & $1.455^{* *}$ \\
\hline & -1.77 & -2.89 & -2.89 & -2.86 \\
\hline \multirow{2}{*}{ COLLATERAL } & $-0.0754 *$ & $-0.0766^{*}$ & $-0.0747^{*}$ & $-0.0745^{*}$ \\
\hline & $(-2.09)$ & $(-2.29)$ & $(-2.20)$ & $(-2.19)$ \\
\hline \multirow{2}{*}{ LEVERAGE } & & $-10.03^{* * *}$ & $-9.848 * * *$ & $-9.876^{* * *}$ \\
\hline & & $(-5.44)$ & $(-5.11)$ & $(-5.12)$ \\
\hline \multirow{2}{*}{ ATAX } & & & -1.119 & -0.342 \\
\hline & & & $(-0.38)$ & $(-0.09)$ \\
\hline \multirow{2}{*}{ MTAX } & & & & -0.768 \\
\hline & & & & $(-0.34)$ \\
\hline \multirow{2}{*}{ _CONS } & -1.637 & 2.27 & 2.11 & 2.095 \\
\hline & $(-1.08)$ & -1.63 & -1.45 & -1.44 \\
\hline $\mathbf{N}$ & 139 & 139 & 139 & 139 \\
\hline
\end{tabular}

t statistics in parentheses, ${ }^{*} \mathrm{p}<0.05,{ }^{* *} \mathrm{p}<0.01,{ }^{* * *} \mathrm{p}<0.001$ 
III: Incomefrom Different Business Models

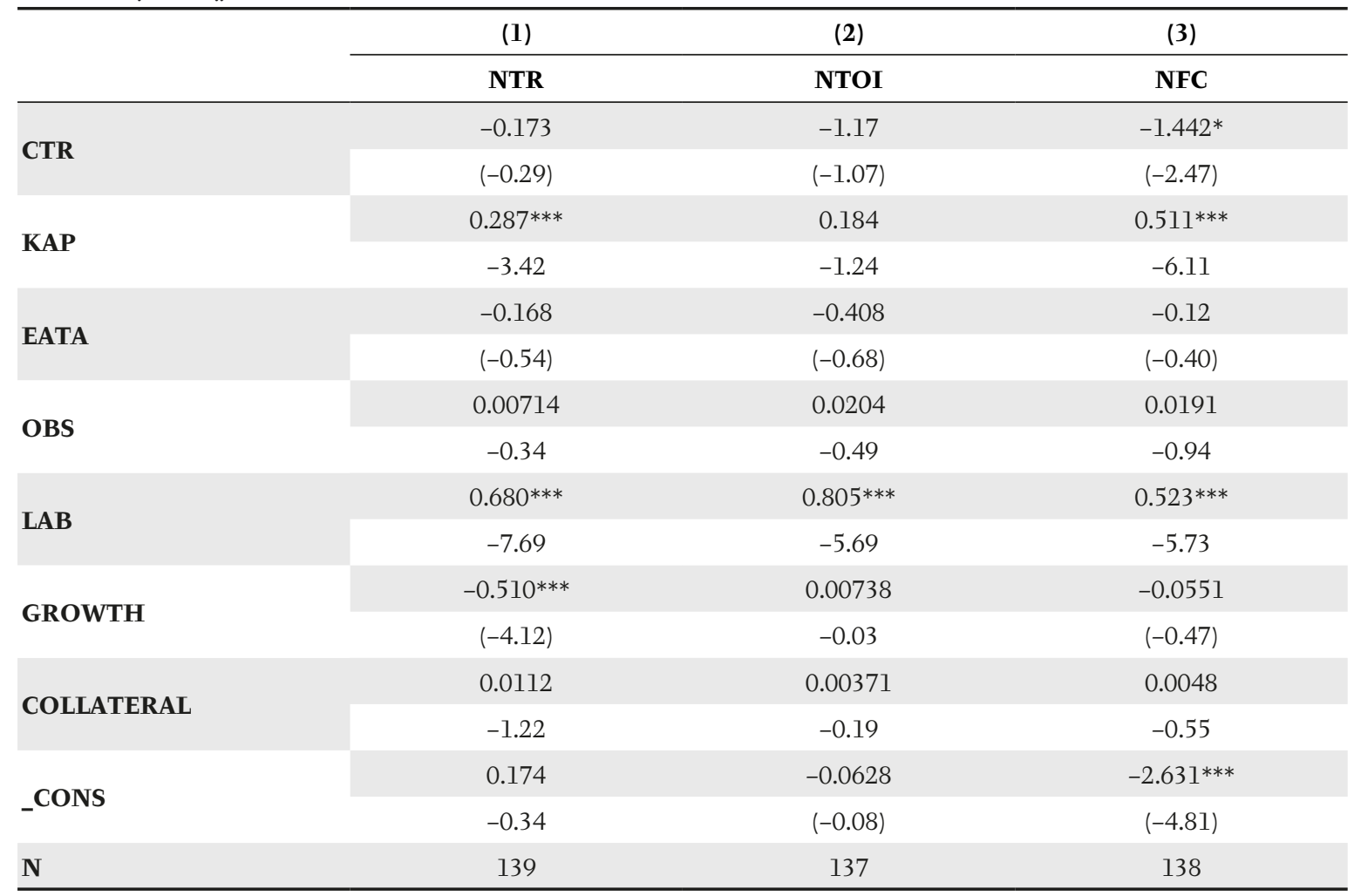

t statistics in parentheses, ${ }^{*} \mathrm{p}<0.05,{ }^{* *} \mathrm{p}<0.01,{ }^{* * *} \mathrm{p}<0.001$

IV: Loan Loss Provisions

\begin{tabular}{|c|c|c|}
\hline & $(1)$ & (2) \\
\hline & LLP & LLP \\
\hline \multirow{2}{*}{ CTR } & -2.99 & -2.938 \\
\hline & $(-1.09)$ & $(-1.19)$ \\
\hline \multirow{2}{*}{ KAP } & 0.498 & 0.108 \\
\hline & -1.31 & -0.31 \\
\hline \multirow{2}{*}{ EATA } & 0.0738 & 0.532 \\
\hline & -0.05 & -0.42 \\
\hline \multirow{2}{*}{ OBS } & -0.149 & -0.148 \\
\hline & $(-1.52)$ & $(-1.70)$ \\
\hline \multirow{2}{*}{ LAB } & 0.682 & 0.0752 \\
\hline & -1.72 & -0.2 \\
\hline \multirow{2}{*}{ GROWTH } & $-2.642^{* * *}$ & $-2.339 * * *$ \\
\hline & $(-4.64)$ & $(-4.67)$ \\
\hline \multirow{2}{*}{ COLLATERAL } & -0.00264 & 0.0156 \\
\hline & $(-0.06)$ & -0.42 \\
\hline \multirow{2}{*}{ PIOP } & & $0.983^{* * *}$ \\
\hline & & -5.65 \\
\hline \multirow{2}{*}{ _CONS } & -2.272 & -1.693 \\
\hline & $(-1.00)$ & $(-0.81)$ \\
\hline $\mathbf{N}$ & 127 & 127 \\
\hline
\end{tabular}




\section{Income from Different Business Models}

In this section we test the tax response of multinational banks using income from other business as our dependent variable, instead of $\ln$ PBT, as suggested by Merz and Overesch (2016). The net interest revenue, non-interest operating income, net fees, and commission are used in our analysis.

The results presented in the above table provide evidence of multinational subsidiary banks' response to taxes using income from different models. Column (1) presents evidence of profit shifting with net interest revenue as the dependent variable. In this column we find insignificant evidence of profit shifting with semi-elasticity of 0.173. In column (2) we use another dependent variable, which is the non-interest revenue, for which similar evidence is found but is not significant.

Moving to column (3), the net fees and commission are used as the dependent variable to seek evidence of profit shifting from other income sources.
The result in the above table is a significant negative coefficient. Merz and Overesch (2016) suggested that such evidence means that shifting profits to low-tax subsidiaries seems to be rather easy.

\section{Loan Loss Provisions}

This section investigates the relationship that exists between the loan loss provision variable and the CTR.

The basis for our argument is that we expect a positive correlation between the CTR and the LLPs. The above table shows the results, in which the loan loss provision is used as the dependent variable. Although we do not achieve the expected results, in column (2) we include the pre-impairment operating profits, which we expect to have a positive impact on the LLPs. It can be seen from the results that a highly significant positive coefficient is recorded. This seems to suggest that banks with higher pre-impairment operating profits accumulate LLPs for future losses as well as means to reduce their tax base.

\section{CONCLUSION}

The aim of this paper was to measure the amount of profit shifting within the banking sector, particularly in Eastern European countries. International taxation and multinational tax planning have attracted public and political attention for some time now due to their adverse effect on countries' public purse. In this study we use a data set from the Bankscope Database compiled by Bureau Van Dijk of 14 countries in Eastern Europe. The approach and method of previous studies are followed and we regress the panel data set for the period of 2006-2015. For the purposes of our analysis, we define a subsidiary bank as having at least $50 \%$ of its shares owned and controlled by the parent company.

Our results show that multinational banks' subsidiaries reported an earnings response to the host country's tax incentives. In comparison with previous studies, the magnitude of the tax sensitivity of the evidence found is substantial. Using income from different models in an additional analysis, we find evidence of the banks using net fees and commission to respond to tax. We perform another task using loan loss provisions, but our results do not agree with the previous findings; however, including pre-impairment operating profits in the model suggests that banks with higher PIOPs accumulate LLPs for future losses as well as means to reduce their tax base.

The results obtained in this study confirm that banks have enhanced tax-planning opportunities similar to firms from different jurisdictions, such as the IT industry or the retailing sector. Therefore, taking into consideration the results obtained in this study, we conclude that, in spite of the measures being put in place by regulators, MNCs are still carrying out activities of profit shifting. We therefore recommend that expedited action be taken to implement the Directive on the disclosure of income tax information, which would in effect require MNCs operating in the EU to draw up and disclose to the public income tax information, including a total breakdown of the profits made, revenues, taxes, and employees.

\section{REFERENCES}

BAGWELL, K. and STAIGER, R. W. 2012. Profit shifting and trade agreements in imperfectly competitive markets. International Economic Review, 53(4): 1067-1104.

BERNARD, A. B., JENSEN, J. B. and SCHOTT, P. K. 2006. Transfer pricing by US-based multinational firms. No. w12493. National Bureau of Economic Research.

BUETTNER, T. and WAMSER, G. 2013. Internal debt and multinational profit shifting: Empirical evidence from firm-level panel data. National Tax Journal, 66(1): 63-95.

CLAUSING, K. A. 2003. Tax-motivated transfer pricing and US intrafirm trade prices. Journal of Public Economics, 87(9): 2207-2223.

CLAUSING, K. A. 2016. The effect of profit shifting on the corporate tax base in the United States and Beyond. National Tax Journal, 69(4): 905-934 
CRIVELLI, E., DE MOOIJ, R. and KEEN, M. 2016. Base erosion, profit shifting and developing countries. FinanzArchiv: Public Finance Analysis, 72(3): 268-301.

DEMIRGÜC-KUNT, A. and HUIZINGA, H. P. 2001. The taxation of domestic and foreign debt. Journal of Public Economics, 79(3): 429-453.

DESAI, M. A., FOLEY, C. F. and HINES, J. R. 2004. A multinational perspective on capital structure choice and internal capital markets. Journal of Finance, 59(6): 2451-2487.

DHARMAPALA, D. 2014. What Do We Know About Base Erosion and Profit Shifting. A review of the empirical literature. Coase-Sandor Institute for Law \& Economics Working Paper No. 702. Chicago: Coase-Sandor Institute for Law and Economics.

DISCHINGER, M. P. 2010. Profit shifting by multinationals: Evidence from European micro panel data. Munich Economics Discussion Paper. Available at: http://www.ecpol.econ.uni-muenchen.de/downloads/publis/ dischinger_publis/dischinger_ps_newl.pdf [Accessed: 2018, May 14].

DISCHINGER, M., KNOLL, B. and RIEDEL, N. 2014. The role of headquarters in multinational profit shifting strategies. International Tax and Public Finance, 21(2): 248-271.

FINKE, K. 2013. Tax avoidance of German multinationals and implications for tax revenue: Evidence from a propensity score matching approach. Available at: http://sbs.ox.ac.uk/sites/default/files/Business_Taxation/Events/ conferences/doctoral_meeting/2013/finke.pdf [Accessed: 2018, May 14].

GROPP, R. and HEIDER, F. 2010. The determinants of bank capital structure. Review of Finance, 14(4): $587-622$.

HAUFLER, A. and SCHJELDERUP, G. 2000. Corporate tax systems and cross country profit shifting. Oxford Economic Papers, 52(2): 306-325.

HECKEMEYER, J. and OVERESCH, M. 2013. Multinationals' profit response to tax differentials: Effect size and shifting channels. ZEW Discussion Paper No. 13-045. ZEW.

HINES, R. and RICE, E. 1994. Fiscal paradise: Foreign tax havens and American business. Quarterly Journal of Economics, 109(1): 149-182.

HUIZINGA, H. and LAEVEN, L. 2008. International profit shifting within multinationals: A multi-country perspective. Journal of Public Economics, 92(5): 1164-1182.

HUIZINGA, H., LAEVEN, L. and NICODEME, G. 2008. Capital structure and international debt shifting. Journal of Financial Economics, 88(1): 80-118.

HUIZINGA, H. P., VOGET, J. and WAGNER, W. B. 2014. International taxation and cross-border banking. American Economic Journal: Economic Policy, 6(2): 94-125.

KRAUTHEIM, S. and SCHMIDT-EISENLOHR, T. 2011. Heterogeneous firms, "profit shifting" FDI and international tax competition. Journal of Public Economics, 95(1): 122-133.

LANGENMAYR, D. and REITER, F. 2017. Trading Offshore: Evidence on Banks' Tax Avoidance. SSRN Electronic Journal. [Online]. Available at: https://papers.ssrn.com/sol3/papers.cfm?abstract_id=3035335 [Accessed: 2018, May 14].

LOHSE, T. and RIEDEL, N. 2013. Do transfer pricing laws limit international income shifting? Evidence from European multinationals. CESifo Working Paper No. 4404. Munich: CESifo.

MAFFINI, G. and MOKKAS, S. 2011. Profit shifting and measured productivity of multinational firms. Oxford Bulletin of Economics and Statistics, 73(1): 1-20.

MERZ, J. and OVERESCH, M. 2016. Profit shifting and tax response of multinational banks. Journal of Banking GFinance, 68(C): 57-68.

OECD. 2013. Addressing Base Erosion and Profit Shifting. OECDiLibrary. [Online]. Available at: https:// www.oecd-ilibrary.org/taxation/addressing-base-erosion-and-profit-shifting_9789264192744-en [Accessed: 2018, May 14].

PERALTA, S., WAUTHY, X., and VAN YPERSELE, T. 2006. Should countries control international profit shifting? Journal of International Economics, 68(1): 24-37.

SWENSON, D. L. 2001. Tax reforms and evidence of transfer pricing. National Tax Journal, 54(1): 7-25.

WEICHENRIEDER, A. J. 2009. Profit shifting in the EU: Evidence from Germany. International Tax and Public Finance, 16(3): 291-297.

Contact information

Daniel Anarfi: anarfidaniel@ymail.com

Danuše Nerudová: d.nerudova@seznam.cz 